P-ISSN : 1412-6141

E-ISSN : $2548-7744$

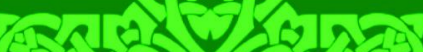
is 120 2ह

51030.

Muhammad Syahran

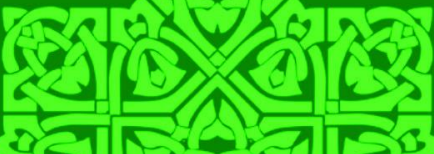
I of Humanities and Islamic Studies

(1) Al-Islām min Al-Ta'àlīm Ilā Al-Taṭbīqāt, Musykilat Al-Jisr Al-
Maqț'

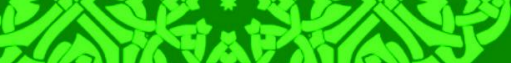

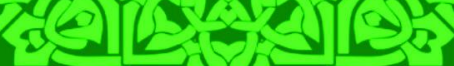

रति 03

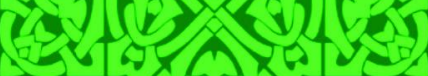

पer

(1)

Salafi and Social Religion Dynamics In Kendari

Muhammad Tahir Alibe, Abdul Muiz Amir

The Infallibility of The Prophet Muhammad Pbuh. As A Human Being (A Study Of His Ijtihad)

Muhammad Saleh Tajuddin The Role of Abdurrahman Wahid in Creating Islamic PostTraditionalist Paradigm in Indonesia

Muh Ilham Usman

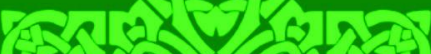

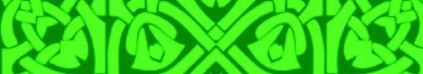
520

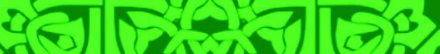
ff 20 is
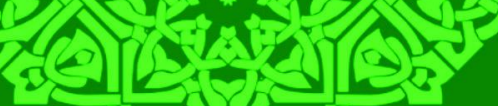

Cर ति 25 (a)

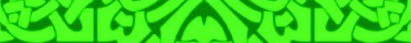
L in $\rightarrow$ Th

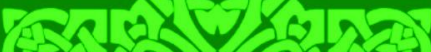
IC म 121 $1<$ 20

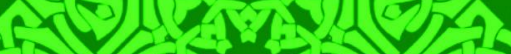

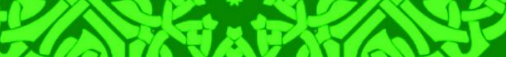

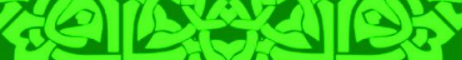

Tasmin Tangngareng, Hasbullah A Prophetic Study On Earthquake

Usman Jafar

Muslims' Thoughts of Non-Muslims' Political Rights in Majority Muslim Areas in Makassar 


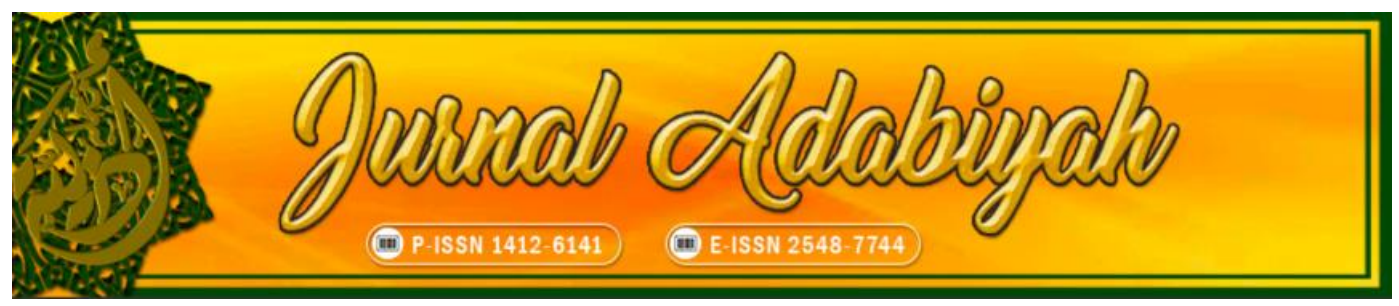

Thema: Islamic Studies

VOLUME 19 NO. 2 DESEMBER 2019

EDITOR-IN-CHIEF

Barsihannor, Alauddin State Islamic University, Indonesia

INTERNATIONAL EDITORIAL BOARD

Nuri Emmiyati, Alauddin State Islamic University, Indonesia

Minako Sakai, Australian National University (ANU), Australia

Abd Rauf Muhammad Amin, Fakulti Syariah Kupu SB Brunei Darussalam, Brunei Darussalam

Muhammad Zakir Husain, Universiti Islam Sultan Sharif Ali, Brunei Darussalam

Muhammad Widus Sempo, Universiti Sains Islam Malaysia, Malaysia

Salih Yousif Sharaf Mohamed, Al-Gazera University, Sudan

Aishah Waenaha Waemamah, Academy of Islamic and Arabic Studies Princess of Naradhiwas University - Thailand, Thailand

EXECUTIVE EDITOR

Umar Thamrin, Universitas Islam Negeri Alauddin, Indonesia

MANAGING EDITOR

Zaenal Abidin, Universitas Islam Negeri Alauddin

\section{EDITORS}

Rosmah Tami, Alauddin State Islamic University, Indonesia

Haniah, Alauddin State Islamic University, Indonesia

Nasrum, Alauddin State Islamic University, Indonesia

Awaluddin Syamsu, Universitas Muslim Indonesia

Ahmadi Usman, UIN Syarif Hidayatullah Jakarta, Indonesia

Baso Pallawagau, Alauddin State Islamic University, Indonesia Muhammad Azwar, Universitas Islam Negeri Syarif Hidayatullah Jakarta, Indonesia

Muh. Saleh Syamsuri, Alauddin State Islamic University, Indonesia

Andi Satrianingsih, Muhammadiyah University, Indonesia

Syahruni Junaid, Alauddin State Islamic University, Indonesia

Rabiatul Adawiah, Majene Islamic State College, West Sulawesi, Indonesia, Indonesia

Chusnul Chatimah Asmad, Alauddin State Islamic University, Indonesia

Nur Arifin, Alauddin State Islamic University, Indonesia

\section{IT SUPPORT}

Taufiq Mathar, Alauddin State Islamic University, Indonesia

\section{LANGUAGE ADVISOR}

Kustiwan Syarief, UIN Syarif Hidayatullah Jakarta, Indonesia

Muh. Saleh Syamsuri, Alauddin State Islamic University, Indonesia

\section{COVER DESIGNER}

Nur Arifin 


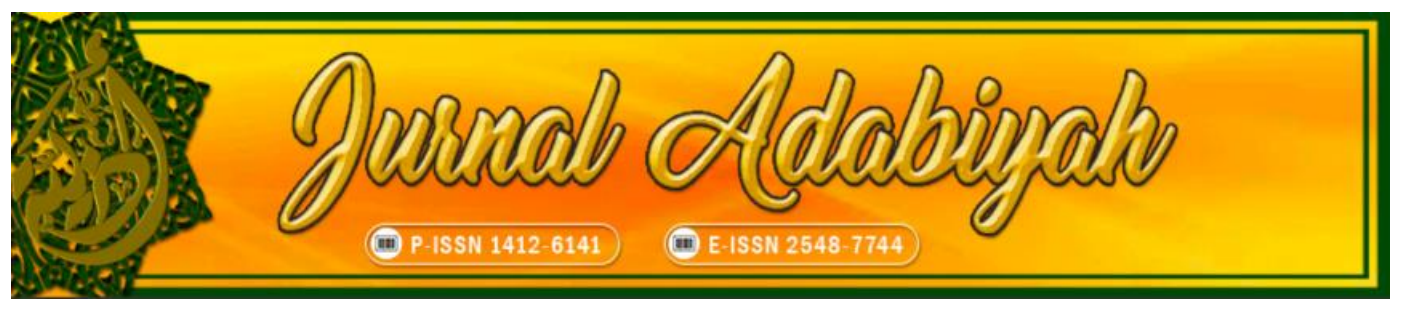

\section{Jurnal Adabiyah:}

This journal receives a national accreditation from Ministry of Research, Technology, and Higher Education Republic of Indonesia, Nomor 10/E/KPT/2019 on April 4, 2019 with the SINTA score: S2.

The Journal has been published by the Faculty of Adab and Humanity of Alauddin State Islamic University, Makassar, since 1997 and has been online since 2016 with the main themes on Humanities and Islamic Studies with the emphasis on interdisciplinary and intertextuality approach.

This journal are published twice a year, on June and December. The themes related to Islamic Studies are textual studies, scriptural traditions, Islamic law, and theology; and those related to Humanities are language, literature, history, and culture.

The journal of Humanities and Islamic Studies will provide the online collection of articles from 1997 up to now. The most updated information can be found on the website. 


\section{Table of Contents}

Muhammad Syahran

103-121

Al-Islām min Al-Ta'ālìm Ilā Al-Tațbīqāt, Musykilat Al-Jisr Al-Maqț'

Abbas

$122-136$

Salafi and Social Religion Dynamics in Kendari

Muhammad Tahir Alibe, Abdul Muiz Amir

137-156

The Infallibility of The Prophet Muhammad Pbuh. As A Human Being

(A Study Of His Ijtihad)

Muhammad Saleh Tajuddin

157-171

The Role of Abdurrahman Wahid in Creating Islamic Post-Traditionalist Paradigm in Indonesia

Muh Ilham Usman

172-185

Islam and Agrarian: Study of Nahdhatul Ulama's Religious Social Thought

Tasmin Tangngareng, Hasbullah

186-203

A Prophetic Study on Earthquake

Usman Jafar.

204-223

Muslims' Thoughts of Non-Muslims' Political Rights in Majority Muslim Areas in Makassar 


\title{
MUSLIMS' THOUGHTS OF NON-MUSLIMS' POLITICAL RIGHTS IN MAJORITY MUSLIM AREAS IN MAKASSAR
}

\author{
Usman Jafar \\ Universitas Islam Negeri Alauddin Makassar \\ Email: jafarusman1958@gmail.com
}

\begin{abstract}
This research endeavors to build an egalitarian social order that emphasizes human equality and eradicates all forms of discrimination based on identities created by the current social system, including race, religion, ethnicity, skin color, nationality, etc. This is done because research into issues of citizen equality within Muslim political systems is an interesting part of discourse regarding national diversity and ideological issues in governance. Using an empirical approach, this study analyzes the involvement of non-Muslims in practical politics and government in Muslim-majority areas such as Makassar. The involvement of non-Muslims in practical politics is key to the creation of a democratic system of governance. This study contributes an explanation as to why the recognition of non-Muslims' political rights must not solely be viewed in terms of theory, but also in terms of normative and practical structures, as Islam promotes democratic governance in which equality, justice, and tolerance are realized well and no political discrimination is committed against citizens. Through this, the purity of Islam can remain undistorted and the gap between the practiced reality among this Muslim-majority population and fundamental Islamic teachings can be bridged.
\end{abstract}

Keywords: Muslim's thought; political rights; non-Muslims; Makassar;

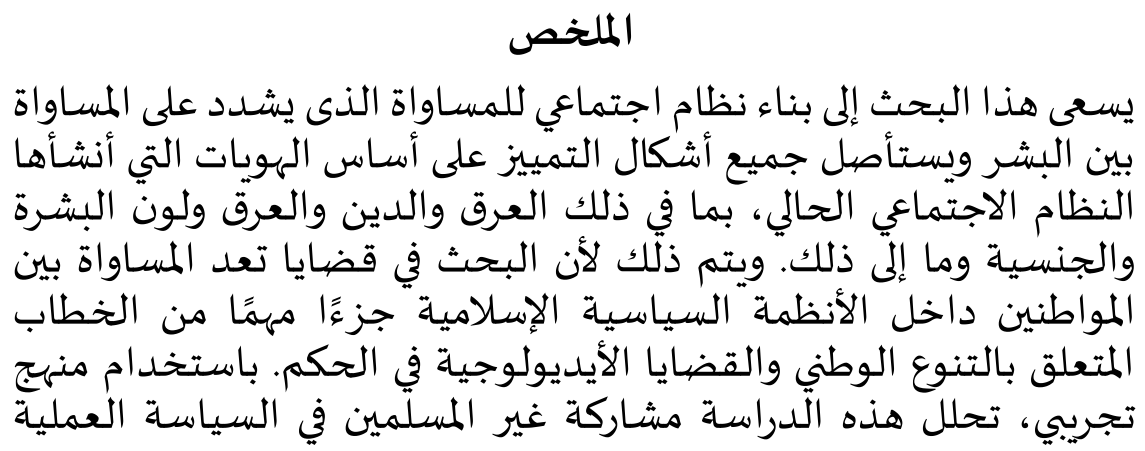




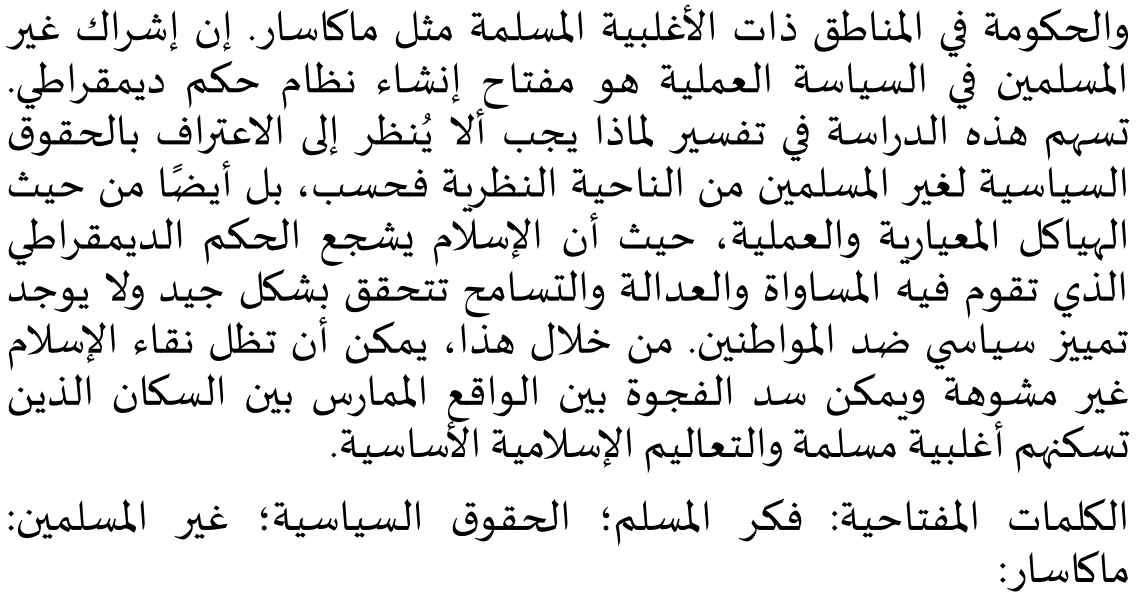

\begin{abstract}
Abstrak
Penelitian ini merupakan ikhtiar untuk membangun suatu tatanan masyarakat egaliter yang diderivasi dari suatu penegasan tentang kesetaraan manusia dan menghapus segala bentuk diskriminasi berdasarkan identitas-identitas yang diciptakan oleh sistem sosial, seperti, perbedaan ras, agama, suku, warna kulit, golongan, kebangsaan dan sebagainya. Sebab isu kesetaraan warga negara dalam sistem politik Islam menjadi kajian menarik dalam wacana menghadapi kemajemukan warga negara dan isu-isu ideologis dalam sebuah pemerintahan. Dengan menggunakan pendekatan empiris, studi ini menganalisis keterlibatan non-muslim dalam politik praktis pada pemerintahan yang mayoritas penduduknya beragama Islam seperti di Makassar. Adanya keterlibatan nonmuslim dalam politik praktis menjadi kunci dalam membangun sebuah pemerintahan yang demokratis. Secara teoritis, studi ini memberikan penjelasan bahwa pengakuan terhadap hak-hak politik non-muslim tidak hanya dipahami pada tataran teoritisnya, tetapi juga pada tataran normative dan praktisnya sebab Islam yang mengusung pemerintahan demokrasi yang bertumpuk pada prinsip-prinsip persamaan, keadilan dan toleransi yang menjadi tuntutan modernitas saat ini dapat berjalan dengan baik, manakala tidak melakukan diskriminasi politik terhadap warga negaranya. Sehingga kemurnian ajaran Islam tidak mengalami distorsi, tetapi kesenjangan yang ada antara realitas masyarakat Islam dengan ide dasar ajaran Islam dapat dijembatani.
\end{abstract}

Kata kunci: Peta pemikiran; hak politik; non-muslim; Makassar; 


\section{A. Introduction}

Discussion of citizens' political rights is an interesting object for research, particularly in the current era of democratization. This issue is present amidst diverse claims regarding the correctness, appropriateness, and absolute obeisance of citizens who differ in the religions they embrace and their political interests. Some citizens claim to have the greatest rights, to be the most correct and appropriate to lead while denying others these rights owing to a perceived lack of correctness and appropriateness. These claims have led to a belief, or doctrine even, that political leadership is solely the right of certain citizens, with other citizens not sharing this right.

It is difficult to transform this claim, even though some persons continue to recognize the State as offering equal political rights to all citizens, both Muslim and non-Muslim. These political rights are guaranteed and recognized, both in legislation and in the constitution, as stemming from citizenship. ${ }^{1}$ These political rights include the right to participate in campaigns for and be elected to the government, be it directly or indirectly through freely chosen representatives, as well as the right to voice opinions freely and recommendations as a form of social control over the government. $^{2}$

These rights are fundamental ones that should be enjoyed by all individuals and groups, for without these rights they could not function as perfect human beings. Furthermore, and more substantively, these political rights simultaneously embody rights and obligations, ${ }^{3}$ as at a certain level these rights are obligatory and required for various individuals. ${ }^{4}$ If these rights are not practiced in making policy and legislation, these rights might be limited and even considered inapplicable to all persons except for those who fulfill certain non-citizenship criteria.

In the context of democracy, understood here as governance of the people, the greatest power is held by the people. It may be practiced by the people directly, or it may be practiced through a system of representation, one that depends on elections that are held periodically and do not distinguish between or privilege certain groups based on their religion or heritage.

This principle of non-discrimination based on class is also found in Islam. The Qur'an recognizes that humans, both Muslims and non-Muslims are equal, as they all

${ }^{1}$ Article 26(1) of the Indonesian Constitution. UUD 45 yang Sudah Diamandemen dengan Penjelasannya, (Surabaya: Karya Ilmu, 2014-2015). p. 19. See also Dede Rosyada et al. Pendidikan Kewargaan (Civic Education): Demokrasi, Hak Asasi Manusia dan Masyarakat Madani, (Jakarta: ICCE UIN Syarif Hidayatullah Jakarta, 2018), p. 74.

${ }^{2}$ Pieter Van Dijk and Peter Baehr, Instrumen Internasional Pokok Hak-hak Asasi Manusia, (Jakarta: Yayasan Obor Indonesia, 2009), p. 231.

${ }^{3}$ A. AhsinThohari, Hak-Konstitusional dalam Hukum Tata Negara Indonesia, (Jakarta: Erlangga, 2017), p. 14

${ }^{4}$ Muhammad Yasir, "Makna Toleransi dalam Al-Qur'an", Jurnal Ilmu Ushuluddin, vol. 22 no.2, (2014): pp. $170-180$ 
originate from God. ${ }^{5}$ No person is more special or of greater quality than another, except in terms of that person's piety, ${ }^{6}$ as reflected in his or her attitudes and charity work. This principle of equality is fundamental to the socio-political ethics developed by Islam as well as the leadership of the Prophet and the four caliphs who followed him. This principle of egalitarianism is clearly one of the most important elements of Islamic socio-political doctrine, and this democratic value has drawn considerable attention to Islam in the past. As such, it offers potential guidelines for Muslims in modern society. ${ }^{7}$

This may be opposed to the attitudes, behaviors, and perspectives that have developed among some residents of Makassar, Indonesia, who have positioned the non-Muslim minority as lacking the specific political right of becoming political leaders in Muslim-majority areas. Some have even termed these non-Muslims dzimmi (نمي), citizens of conquered lands, second-class citizens beneath Muslims. This view has been influenced by classical Islamic jurisprudence (أصول الفقه) as well as the views of Muslim jurors such as Sayyid Quthub, Sayyid Hawa, and Abu A'la Al-Maududi, who proscribed similar prohibitions. ${ }^{8}$

Wisdom is required to reconstruct existing typologies and reexamine various interpretations (ijtihad, اجتهاد) as linked to political issues and the position of nonMuslim minority populations in Muslim-majority areas. In this manner, this issue may be examined proportionally, with all distortions of Islamic doctrine clarified. Only then will the gap between the practiced reality of Muslim society and the fundamental teachings of Islam be bridged.

This study examines the issue of political leadership. How may a non-Muslim, for example, become the head of a Muslim-majority state or political leader of a Muslim-majority area as a realization of Islam's high regard for egalitarian principles. This issue will be analyzed empirically and theoretically, involving several research variables, namely: how far do the political rights of non-Muslims in Muslim-majority areas extend; how do they influence government efficiency; and what are the attitudes and views of Muslims in Makassar regarding the political rights of the non-Muslim minority.

\section{B. Theoretical Framework}

This analysis of non-Muslims' political rights in Muslim-majority areas is based on the rational conceptual framework constructed through the Qur'an and Sunnah, which serve as the conceptual basis for life management, including the

${ }^{5}$ Q.S. An-Nisa: (4):1.

${ }^{6}$ Q.S, Al-Hujurat: (49):13.

${ }^{7}$ Nurcholish Madjid, Islam Kemoderenan dan Keindonesiaan, (Bandung: Mizan, 1987), p. 79. See also Usman, "Persamaan Dalam Islam" (Telaah Atas Pemikiran Politik Islam), Al-Daulah Jurnal Hukum Pidana \& Ketatanegaraan, vol. 5, no.1 ( Juni 2016): p. 6

${ }^{8}$ Sayyid Quthub, Fi Zilal Al-Qur'an, Vol. 2, (Beirut: Dar al-Syuruq, n.d.), p. 907. See also Sayyid Hawwa, al-Madkhal Ila Da'wah Ikhwan al-Muslimin, (s.l, s.n, nd.), p. 346. 
management of the socio-political affairs at the basis of political systems and legislations.

As explained by Louis Marlow, the Qur'an explores principles of equality. ${ }^{9}$ It emphasizes both the oneness of God as well as the equality of all persons created by Him. ${ }^{10}$ In principle, Marlow continues, monotheist religions consider their followers to be brethren, even when they originate from different areas. Such a view cannot be separated from the belief that all humans are equal in God's eyes. ${ }^{11}$ Religious and moral egalitarianism can be found in the Qur'an as well as the holy texts of other religions. The Qur'an, as with previous holy books, teaches much about morality and its use in social life but requires humanity to apply this morality in life. ${ }^{12}$

In this, humans are positions as the "managers" or "rulers" on Earth, without any distinction being made between them. Management and rule involve various social and political aspects. It would be naïve to assume that this management and rule is entrusted solely to certain persons or people from a certain religion. ${ }^{13}$ As such, the principle of leadership has become the basis for modern political theory, which positions all people as enjoying the same political right to "manage" and rule over the earth, or, to use a more popular term, to become head of state. Anyone, Muslim or non-Muslim, may become a leader as long as he or she has the necessary quality and ability to promote prosperity and political stability. ${ }^{14}$

Abdullah Ahmed An-Na'im holds that, because governance gives the greatest emphasis to citizenship, there is no longer any need to differentiate between Muslim and non-Muslim citizens in protecting the political rights related to government and governance. ${ }^{15}$ Because all citizens are the same and equal in participatory politics, it is inappropriate for a prohibition of non-Muslim leadership to be based on Verse 28 of the Sura Ali Imran, because this verse was revealed when relations between Muslims and non-Muslims were colored by enmity, rather than an atmosphere of mutual support and benefit. Owing to the contemporary situation, it is understandable

Louis Marlow, Masyarakat Egalitarian, (Bandung: Mizan, 1999), p. 7. See also Babi Aswandi dan Chalis Raisah, "Negara Hukum dan Demokrasi Pancasila dalam kaitannya dengan Hakhak Asasi Manusia (HAM)", Jurnal Pembangunan Hukum Indonesia, vol. 1, no. 1, (tahum 2019), p. 129

${ }^{10}$ Q. S. An-Nisa, (4): 1.

${ }^{11}$ Q. S. Al-Hujurat, (49):13.

${ }^{12}$ Louis Marlow, Masyarakat Egalitarian, p. 7

${ }^{13}$ Ali Mhammad Ash-Shalabi, Ad-Daulah Al-Haditsah Al-Muslimah: Do'a 'imuha wa Wazha'ifuha, terj. Ali Nurdin, Negara Islam Modern; Menuju Baldatun Thayyibatun wa Rabbun Ghafur, (Jakarta Timur: Pustaka Al-Kausar, 2017), p. 23

Ali Muhammad Ash-Shalabi, Ad-Daulah Al-Haditsa Al-Muslimah; Do'a 'imuha wa Wazha'ifuha, terj. Ali Nurdin, Negara Islam Modern; Menuju Baldatun Thayyibatun wa Rabbun Ghafur, pp. 23-24.

${ }^{15}$ Abdullah Ahmed An-Na'im, Islam dan Negara Sekuler: Menegosiasikan Masa Depan Syari'ah, (Bandung: Mizan Pustaka, 2017), p. 197. 
that this verse forbids Muslims from establishing political alliances with nonMuslims. However, at the same time, "Allah does not forbid you from those who do not fight you because of religion and do not expel you from your homes - from being righteous toward them and acting justly toward them. Indeed, Allah loves those who act justly." 16

Acting kindly and justly, in this context, includes recognizing the political rights of non-Muslims and avoiding any discrimination against citizens from different religious backgrounds in social life. Based on this, Syekh Syaukat Hussain views Islam as not recognizing any dichotomy between worldly and spiritual life. At its essence, Islam offers a religio-political system, in which the State is but one manner in which spiritual goals can be realized by humanity. Humanity's worldly and spiritual lives are intended to be mutually complementary and to be realized concurrently. Worldly activities are not limited to Muslims; they may be undertaken by anyone, including non-Muslims. ${ }^{17}$

As such, the political rights of citizens are a manifestation of the human desire to participate in governance. In the literature of political rights, such rights are frequently considered fundamental human rights. ${ }^{18}$ The basis of all human rights is the assumption that all people must have equal opportunity to develop in accordance with their own talents and dreams. ${ }^{19}$ This includes leaders, as persons who must bear the burden of responsibility. As humanity's responsibility must begin with freedom of choice, freedom is an inseparable part of this responsibility. Furthermore, freedom can also be understood as a way of honoring humans' dignity as servants of God and as leaders, managers, and rulers on Earth. ${ }^{20}$

This principle lies at the root of the political theory in Indonesia, a country with a plural population, that there are no issues with non-Muslim involvement in governance. This view, aside from being part of human rights, is also manifested in the spirit and passion of the 1945 constitution, ${ }^{21}$ as well as the theory of "constitution" in which all citizens are the same and enjoy equal political rights, in this case, the

${ }^{16}$ Q. S. Al-Muntahanah, (60):8.

${ }^{17}$ Syekh Syaukat Hussain, Hak-hak Asasi Manusia dalam Islam, (Jakarta: Grma Insani Press, 2018), p. 9

${ }^{18}$ Sirajuddin dan Winardi, Dasar-dasar Hukum Tata Negara Indonesia, (Malang: Setara Press, 2015), p. 243

${ }^{19}$ Meriam Budiardjo, Dasar-dasar Ilmu Politik, (Jakarta: Gramedia Pustaka Utama, 2012), p.120.

${ }^{20}$ Rusjdi Ali Muhammad, Hak-hak Asasi Manusia Dalam Perspektif Syari’at Islam, (Jakarta: Ar-Raniry Press, 2014), p. xiiv.

${ }^{21}$ Abdurrahman Wahid, "Presiden dan Agama", in Politik Demi Tuhan: Nasionalisme Religius di Indonesia, (Bandung: Pustaka Hidayat, 1999), pp. 30-35. See also Edwin M.B. Tambunan, "Demokrasi, Sistem Pemilu, dan Pengelolaan Kinflik Etnik", Jurnal Ilmu Sosial dan Ilmu Politik, vol. 5, no. 19, (Juni 2019), p. 1. 
political right to participate in government and governance. ${ }^{22}$ Political rights are to be enjoyed by all persons, regardless of creed, for without these rights they cannot realize their functions as perfect human beings. These rights include freedom of expression, without any interference; freedom of association and assembly; the right to participate in the governance of one's country, be it directly or indirectly through freely elected representatives; and the right to equal opportunity to occupy a government position. ${ }^{23}$

Philosophically, the basis for good governance must be free of discriminative, sectarian, or tyrannical political treatment and behavior. The system must be democratic and constitutional, with the people - not excepting non-Muslimsdetermining the processes through which the government acts. If they are capable of freeing themselves of the shackles of labels and the class distinctions and privileges attached to them, a constitutional government may be realized. It should include at least three main elements. ${ }^{24}$ First, it must be constitutional. The government must be built upon a constitution embodying the people's agreement to be ruled through a framework of rights and obligations determined by the people, including non-Muslim citizens.

Second, it must be participatory. The political system, including the institutional formation of the government structure, is participatory. Leadership and policymaking are rooted in public participation, as realized through elections. Muslims can use their own creativity, based on Islamic guidelines and the precedent of the prophets, to institutionalize and improve various processes. In Islam, this participatory aspect is realized through a process called syura (شورى.). Third, it must offer accountability. This point is an essential corollary of the constitutional/participatory system. Leaders and authority-holders are selected by the people, and as such they must be accountable to the people.

The above perspective meshes with the concept of nationhood and the nationstate, in which all citizens are the same and equal before the law, without differentiating them based on their religion. Muslims and non-Muslims are equal in governance. Presently, this understanding of nationhood has driven modern society to place greater emphasis on the egalitarian concepts of tolerance, justice, and democracy, through which citizens' political rights can be truly realized in social, political, and national life.

\section{Empirical Findings on Muslims' Involvement in Practical Politics in Makassar}

To investigate the above issue, the author conducted field research, using a purposive approach to identify 10 informants from Islamic civil organizations, and

${ }^{22}$ UUD '45 yang Sudah Diamandemen dengan Penjelasannya, p. 21.

${ }^{23}$ Pieter Van Dijk and Peter Baehr, Instrumen Internasional Pokok Hak-hak Asasi Manusia, edisi kedua, (Jakarta: Yayasan Obor Indonesia, 2017), p. 231. See also Edwin M.B. Tambunan, "Demokrasi, Sistem Pemilu, dan Pengelolaan Kinflik Etnik", Jurnal Ilmu Sosial dan Ilmu Politik, vol. 5, no. 19, (Juni 2019), p. 1.

${ }^{24}$ Kompilasi Hukum Tata Negara, Edisi Paling Lengkap, (Yogyakarta: RIAK, 2017), p. 56. 
Islamic political parties that are proactive in practical politics. Data collection was conducted using the techniques of observation, interviews, and literature review. Using a qualitative analysis with naturalistic tendencies as well as a phenomenological approach, it was concluded that non-Muslims enjoy the same political rights as Muslims in managing their social lives, including governance. These political rights include the right to participate in and be selected for governance, be it directly or indirectly through freely elected representatives; as well as the right to voice views, opinions, and recommendations as a form of social control of the government. ${ }^{25}$ These rights are fundamental ones that should be possessed by all individuals and groups, for without these rights nobody could function as a perfect person.

The main principle in fulfilling the rights of non-Muslims is their involvement, be it direct or through representatives, in all political policymaking and decision-making processes as part of the social contract regarding governance and control, because it is normatively recognized that non-Muslim citizens, working together with Muslim citizens, had an integral role in ensuring the independence of the nation. As such, they cannot be forced outside of the political arena or forbidden from promoting their own political interests or those of the community at large. This is one basis for egalitarianism and equal treatment of citizens, without any consideration of their religious backgrounds or faiths, and legislation has offered an open door for non-Muslim citizens on the stage of practical politics.

Field data indicate that, in the 2014 regional elections, 915,094 of Makassar's 1,223,540 residents fulfilled the criteria outlined by Article 13 of Law No. 12/2003 regarding General Elections, namely being 17 years of age or having already married. ${ }^{26}$ This number of potential voters includes non-Muslims. This indicates that non-Muslims possess political rights and have practiced them in recent years through the elections, both as voters and as candidates. The non-Muslim community has represented itself through five legislative members in the national parliament, regional parliament, and the Regional Representative Council. These representatives are backed by several nationalistic political parties: the Prosperous Peace Party (Partai Damai Sejahtera, PDS), Party of the Service Society (Partai Golongan Karya, GOLKAR), Indonesian Democratic Party of Struggle (Partai Demokrasi Indonesia Perjuangan, PDI-P), Indonesian Justice and Unity Party (Partai Keadilan dan Persatuan Indonesia, PKPI), as well as the police/military. ${ }^{27}$ As such, they have a bargaining position to negotiate political interests from various groups and political parties at different levels of government.

${ }^{25}$ Pieter Van Dijk and Peter Baehr, Instrumen Internasional Pokok Hak-hak Asasi Manusia, p. 231.

${ }^{26}$ Kompilasi Hukum Tata Negara, Edisi Paling Lengkap, (Yogyakarta: RIAK, 2017), p. 56. See also Usman, "Pilkada Dan Konflik Horizontal: Telaah Atas Pemilukada di Kota Makassar", AlDaulah Jurnal, Hukum Pidana \& Ketatanegaraan, vol. 7, no.2 ( Desember, 2018): p.. 332

${ }^{27}$ Interview with H. Abd. Hamid, (48 tahun), spokesman for the Wahda of Makassar, Makassar 28 July 2019 
Empirical data thus indicates that the non-Muslim community's presence in the political arena affects the effectiveness of governance and politics. They are involved in political dynamics (i.e. change) at the social structure level and in the existing political institutions. They are, together with other politicians and the elected government, involved in policymaking decisions and the formulation of regulations and laws applicable to social life. In this political situation and condition, there is thus competition between different political interests, creating even greater political dynamics that functionally lead to the democratic interactions expected of a modern government.

\section{Limitations on Non-Muslims' Involvement in Strategic Positions}

The question of non-Muslim leadership, as discussed above, embodies the question of whether or not non-Muslims have the political right to be elected or selected for political leadership positions (president, governor, mayor, etc.) in areas with a majority Muslim population. There are at least two views on this issue that have developed in the Muslim community. These are, first, the view that rejects nonMuslims' political right to become leaders in Muslim-majority areas or Muslim states, and second, the view that accepts or supports said political right.

First is the group that rejects non-Muslim leadership. This group refers to an ideological concept, arguing that, in States with Muslim ideology, non-Muslims lack the political rights to become government leaders and govern Muslim-majority populations. In an Indonesian context, including Makassar, no Islamic ideology lies behind the system of governance. However, as most of the population is Muslim, this group argues that non-Muslims still lack such a political right. This view is supported by Salafi and Wahdah Islamiyah. ${ }^{28}$

According to these Islamic organizations, non-Muslims' political rights are limited solely to general citizen rights: the right to assemble, associate, and form political parties, the right to voice opinions as a form of social control, the right to receive fair and just service from the government, and the right to vote and be elected. This last right is limited solely to technical positions, such as Member of Parliament, Agency Chief, Office Chief, etc. These groups consider it acceptable for such positions to be allocated to both Muslims and non-Muslims, who can fulfill administrative and other technical tasks. However, these groups consider nonMuslims to lack the right to become president, governor, mayor, or regent. ${ }^{29}$

These groups consider it acceptable for non-Muslims to occupy technical positions because they view non-Muslims as what classical Islamic jurisprudence terms dhimmi, persons bound in an agreement with a Muslim government. However, these non-Muslims' fundamental rights are still respected, and they are still protected and allowed to live freely, including in finance and in worship. The government may

${ }^{28}$ Interview with Sri Atika, (45 tahun), spokesman for the Salafi of Makassar, 27 July 2019. And H. Abd. Hamid, (48 tahun), spokesman for the Wahda of Makassar, Makassar 28 July 2019

${ }^{29}$ Interview with H. Abd. Hamid, (48 tahun), spokesman for the Wahda of Makassar, Makassar 28 July 2019 
not force them to pray in a Muslim manner. Non-Muslims may worship, dress, eat, and marry in accordance with their own religions and faiths. However, they must still follow the rules implemented by the government through its legislation. The first group considers this part of an agreement between the government and the State's non-Muslim population. ${ }^{30}$

Second is a group that accepts and recognizes non-Muslims' political rights as being equal to those of Muslims, including the right to be elected as public leaders and handle governance in Muslim-majority areas. This group argues that, owing to the situation in modern times, the concept of a State based in Islamic ideology is no longer relevant; countries, they argue, are now nation states, based on a shared nationality, rather than being based on religion. This understanding of nationality can be seen from the plurality of citizens, religions, cultures, customs, and tribes in modern states, such as Indonesia, and this both demands and guarantees that all citizens have equal rights (including political rights) and obligations, without any consideration of their religion or beliefs. ${ }^{31}$

Such a view is held by several Islamic organizations in Makassar, including Muhammadiyah, Nahdlatul Ulama (NU), the Islamic Preachers' Council (Dewan Dakwah Islamiyah, DDI), and the Indonesian Institute of Islamic Dawah (Lembaga Dakwah Islam Indonesia, LDII), as well as Islamic political parties such as the United Development Party (Partai Persatuan Pembangunan, PPP), Reform Star Party (Partai Bintang Reformasi, PBR), Crescent Star Party (Partai Bulan Bintang, PBB), and Prosperous Justice Party (Partai Keadilan Sejahtera, PKS.

Likewise, within the Indonesian Constitution, there is no requirement for the national political leader (i.e. the President of Indonesia) to be Muslim. As such, it can be understood that all Indonesian citizens, including non-Muslims, have the political right to be elected as a political leader. The fact that the Indonesian president is not required to be Muslim can be seen in Article 6, Paragraph (1) of the 1945 Constitution as well as Article 6 of the Law on Presidential and Vice-Presidential Elections (Law No. 23/2003), which explicitly defines the criteria all presidents must meet. As long as Article 6, Paragraph (1) of the 1945 Constitution and Article 6 of the Law on Presidential Elections are not amended or annulled, these criteria will continue to apply. ${ }^{32}$ Meanwhile, in Islamic jurisprudence, there is the principle of istishab (ستصحاب,)a presumption that existing laws remain in effect until new laws change or annul them. As related to the issue of non-Muslims political rights, this can be understood to mean that, so long as the Indonesian Constitution does not require

\footnotetext{
${ }^{30}$ Interview with H. Abd. Hamid (48 tahun), spokesman for the Wahda of Makassar, Makassar, 28 July 2019.

${ }^{31}$ Interview with K.H. Sanusi, (59 tahun), spokesman for the Muhammadiyah of Makassar, Makassar, 27 July 2019.

${ }^{32}$ Kompilasi Hukum Tata Negara, Edisi Paling Lengkap, (Yogyakarta, RIAK, 2007), pp. $223-$ 224. See also UUD 45 yang Sudah Diamandemen dengan Penjelasannya (Surabaya: Karya Ilmu, 2014-2015), p. 4.
} 
the Indonesian president to be Muslim, non-Muslims will enjoy the same political right as Muslims, namely the right to be elected to leadership positions. ${ }^{33}$

In this context, it is important that Muslim citizens and non-Muslim citizens are considered equal before the State. The State cannot be subordinated into a single religion. ${ }^{34}$ It must be understood as separate from of any one religious group. Muslims are part of Indonesian society. Only in this manner can Muslim citizens open effective communications and interactions with the broader, pluralistic Indonesian society, and together shape a State and nation that is democratic, modern, and egalitarian, as realized through its civil society.

The Muslim community's shared views, shaped through the elites in Islamic-based organizations and political parties, have led to considerable polarization. This is unavoidable, given that it is linked to ideological issues that are seen as positioning non-Muslim citizens in a discriminative manner.

\section{E. Contextualizing Muslims' Political Thought: Giving Non-Muslims Strategic Positions and Space in Practical Politics}

Based on the analysis of Muslims' political thoughts, as manifested in the two different groups discussed above, it appears that both intend to create an Islamic social order, in accordance with the doctrine of the Holy Qur'an and Sunnah. However, these groups' different interpretations said doctrine indicates an important distinction. The first group rejects non-Muslims having a specific political right, namely the right to become a political leader within a Muslim-majority area. This group uses a scripturalistic approach, emphasizing a literal and denotative understanding and interpretation of Islamic doctrine, as well as historically consecrated practice. This group considers doctrinal commands and prohibitions to be eternal, without any potential for human interference. In other words, scriptural commands and prohibitions are a divine scenario that has been realized since time immemorial. This group does not recognize the historical reality involved, nor does it contemplate the temporal distance between when members acquired this knowledge and when the text was written, as well as the developments that occurred in this time frame.

This group considers doctrinal ordinances total and absolute. For them, no aspect of human life is without influence from said doctrine. As such, ijtihad must be limited solely to issues where existing doctrine offers no clear guidance or detailed regulations.

Owing to this understanding, the first group views precedents from early Islam to be wholly binding, meaning that said precedents are binding not only in their principles

${ }^{33}$ Mary Silvita, "Presiden Non-Muslim dalam Komunitas Masyarakat Muslim”, Islamica: Journal Studi Keislaman, vol. 7 (1), 2012, p. $44-60$.

${ }^{34}$ Mahathir Muhammad Iqbal. "Dinamika Wacana Formalisasi Syariat dalam Politik: Ikhtiar Menemukan Relevansi Relasi Agama dan Negara Perspektif Indonesia", Walisongo: Jurnal Penelitian Sosial Keagamaan, vol. 22 (1), 2014, p. 83 - 104. 
but also in their details. This group views life in the early Islamic period, the time of the Prophet Muhammad and his companions, as an ideal that must forever be realized. As such, the ijma' (إجماع), or consensus on religious questions, reached by the Prophet's companions will continue to apply to Muslims until the end of time. This ijma' cannot be changed by any consensuses reached after the time of the Prophet. Such a view shows great appreciation for historical Islamic heritage and traditions, from the time of the tābi'un (التابعون), the generation born after the Prophet's death but contemporary to the companions, and the tābi al-Tābi 'un (تابع (التابعين the generation born after the, (täbi'un. In this tradition, the Islamic thought passed through generations of scholars retains its authority.

According to Yusril Ihza Mahendra, as quoted by Usman Jafar, the view held by this first group tends to consider pluralism negatively and pessimistically. Society tends to be viewed in "black and white", with Muslims who wholly believe and practice Islamic doctrine opposed to the jahiliyah (جاهلية), the "ignorant" who do not believe or practice this doctrine. Human history is viewed as a history of contestation between these two groups, as symbolized by the prophets and their opponents. With society so divided, hikmah (حكمة) or wisdom can never be gained from the jahiliyah. As such, this view is closed to potential adaptation and acculturation with other societies or their cultures. Humans are faced with only two choices: they may become mu'min (مؤمن) "unbelievers". It is these unbelievers, these nonMuslims, whom the first group considers lacking the political right to govern public interests, particularly in governments where most of the population is Muslim. ${ }^{35}$

In accordance with this principle, the first group also maintains the concept of an ideological State as well as the concept of dzimmi, which has been inherited over the ages. For this group, the State must be based on religion. As a logical consequence, the leader of the State must be a caliph or use a similar title and have two main duties: to keep the faith and govern worldly affairs. In religion, the caliph must lead Friday prayers as an imam, serve as Amir al-Haj (أمير الحج), or leader of the hajj pilgrimage, and become khatib (خطيب, deliverer of sermons) on holidays such as Eid al-Fitr and Eid al-Adha. In politics, meanwhile, the caliph simultaneously holds three types of power: executive, legislative, and judiciary ${ }^{36}$ As such, the caliph has significant power over both religious affairs and worldly (political) ones. ${ }^{37}$ The dzimmi, conversely, are considered second-class citizens and beneath Muslims. Owing to this position and status, in the first group's view they may not hold the political right to lead a Muslim-majority population.

\footnotetext{
${ }^{35}$ Usman Jafar, Egalitarianisme dalam Islam: Refleksi Pemikiran Atas Hak-hak Politik Minoritas Non-Muslim di Tengah-tengah Mayoritas Muslim, (Makassar: Alauddin University Press, 2016), p. 190

${ }^{36}$ Abdul al-Wahab Khallaf, al-Siyasah al- Syar'iyah aw Nizham al-Dawlah al-Islamiyyah fi al-Sur'un al-Dusturiyyah wa al-Kharajiyyah wa al-Malikiyah, (Cairo: Dar al-Anshar, 1977), pp. 5960. See also M. Dhiauddin Rais, Teori Politik Islam (Jakarta: Gema Insani, 2018), pp. 78-87.

${ }^{37}$ Mujar Ibnu Syarif, Presiden Non-Muslim di Negara Muslim. (Jakarta: Pustaka Sinar Harapan, 2019), pp. 6-7.
} 
The second group, meanwhile, supports or at least accepts non-Muslims political rights, including the right to become political leaders and practice governance, be it at the central or municipal/regency level. This group attempts to interpret doctrine in a more actual and rational manner than the first group. The commands and prohibitions in Islamic doctrine, this group argues, should not be considered eternal. They may be contextualized in accordance with the dynamics of history and social reality, cannot be free of human intervention, and have not been realized since time immemorial.

This group tends to interpret doctrine in a more elastic and flexible manner. In its interpretation, this group holds that, when it comes to social issues such as politics, Islamic doctrine only offers general guidelines that apply universally. As such, ijtihad must continuously be practiced, for through this interpretation the general guidelines of doctrine can be implemented more concretely in the context of a specific society, unique in place and time.

In accordance with its understanding of doctrine, this group considers early Islamic traditions, as practiced by the Prophet and his companions, particularly during the time of Rashidun (الخلفاء, rightly guided) caliphs, as only binding in their principles, rather than their specifics. ${ }^{38}$

In general, this group bases its argument on society being dynamic rather than static. Society continues to change and develop over time, with no individual being capable of stopping its transformation. Likewise, though the essence of the principles regarding human behavior in society, such as normative understandings of good and evil, remain constant, these principles' specific understandings change over time. As such, the early precedent set in the time of the Prophet and his companions need not be followed in its specifics; the situation has changed. This change, Yusril writes, is "God's Path", and must be followed by His faithful. The history and traditions in early Islam - the generations of the companions, the tabi'un, and the täbi 'al-Tábi 'unfocused predominantly on contemporary concerns and aspirations. As such, the traditional heritage of this period need not bind Muslims from subsequent generations. ${ }^{39}$

This group tends to have a positive and optimistic attitude towards pluralism, which leads to openness and tolerance. Hikmah, the group argues, can be found anywhere on Earth, including among non-Muslim peoples and groups. Owing to this understanding of hikmah, this group tends to be more open to adapting and acculturating principles and lessons from other societies. The search for wisdom tends to be oriented towards solving concrete problems using a pragmatic and

${ }^{38}$ Usman Jafar, Egalitarianisme dalam Islam: Refleksi Pemikiran Atas Hak-hak Politik Minoritas Non-Muslim di Tengah-tengah Mayoritas Muslim, p. 191

${ }^{39}$ Usman Jafar, Egalitarianisme dalam Islam: Refleksi Pemikiran Atas Hak-hak Politik Minoritas Non-Muslim di Tengah-tengah Mayoritas Muslim, p. 192 
compromistic approach. In this manner, Islamic teachings can meet the challenges of modern times. ${ }^{40}$

This group view states in the modern era as generally being based on a concept of nation, rather than religion. As such, the political power of government leaders is limited by law; in Indonesia, this means that government leaders only have executive power and may only hold office for five years before a new election is required. As such, the positions of imam during Friday prayers and khatib at the mosque - duties that, together with political duties, were central to the position of the caliph in classical Islam - have since been filled by other Muslims, who are not head of state but still have the necessary capacity. While in the classic period heads of state held religious and political authority simultaneously, in modern times the head of state only holds political authority.

This group's understanding of dzimmi has also shifted. Previously, Muslims' socio-political conditions were oriented more towards conquest in the name of expanding their political power. Many non-Muslims thus lived in conquered lands and received dzimmi status, recognitionascitizens who were granted political protection by Muslim rulers. This socio-political condition has changed considerably since then. Muslims are presently more oriented towards building relations between different religious communities in an atmosphere of peace, tolerance, and equality, leading to life in pluralism. ${ }^{41}$

The main shortcoming of this first group's view, which tends to be literal and denotative, is that it fails to address the complex issues that have emerged and developed in modern life. Meanwhile, the second group's view, which tends to be more liberal and contextual, offers effective solutions to the issues that have emerged and developed in modern life. However, this second group's approach may face strong opposition from radical Muslims, who do not believe the second approach to be based in Islamic tradition.

To bridge these two groups' views, their reasoning must be examined in the context of why non-Muslims are considered to lack the political right to become government leaders in Muslim majority areas. Second, verses regarding this political right should be understood holistically, not partially or separately. More specifically, verses of prohibition should be linked to or compromised by verses that allow political rights.

The first group's view, as explored above, is based on a prohibition for Muslims to select non-Muslims as political leaders in countries where Muslims represent the majority of the population, a prohibition itself based on the assumption that non-Muslims are enemies of Islam and Muslims. If this basis were eliminated, the prohibition would likewise be eliminated, in accordance with the principle al-

\footnotetext{
${ }^{40}$ Usman Jafar, Egalitarianisme dalam Islam: Refleksi Pemikiran Atas Hak-hak Politik Minoritas Non-Muslim di Tengah-tengah Mayoritas Muslim, p. 192

${ }^{41}$ Moh Rosyd, "Harmoni Kehidupan Sosial Beda Agama dan Aliran di Kudus", Journal Addin, vol. 17 no.1, (2013): pp. 41 - 64.
} 
hukmu yaduru ma'a 'illatihi wujudan wa 'adaman (the ability to apply or not apply a law depends on its basis). ${ }^{42}$

In this context, the author disagrees with the first group, which is represented in Makassar by such Islamic organizations as Hizb ut-Tahrir and Wahdah Islamiyah, as well as scholars such as Sayyid Quthub, Sayyid Hawa, and Abu A'la Al-Maududi, who generalize all non-Muslims as evil and enemies of both Islam and Muslims and thus prohibit them from being selected as public and government leaders in Muslimmajority areas.

It must be recognized as the historical fact that some non-Muslims committed wrongs towards Muslims or become enemies of Islam, such as the Quraysh polytheists in Mecca and the Jews of Medina, both of whom targeted the Prophet. However, it is rather inaccurate to use the wrongs perpetrated by non-Muslims against Islam and Muslims since the Prophet's time, such as in Baghdad, Andalusia, India, Spain, and Ethiopia (examples used by Sayyid Quthub and Sayyid Hawa) as the basis for generalizing that all non-Muslims will bring evils to Muslims and enmity to Islam when in power. As already recognized by Quthub, Negus - a Christian king of Ethiopia contemporary to the Prophet-was kind and friendly in welcoming Muslim emigrants from Mecca and greatly respected Islam. ${ }^{43}$

This illustrates how both religious communities follow the religion of God, recognize His presence, and teach truth and morality. Events of five hundred years ago should be remembered to ensure friendlier and more humane relations. A prominent Christian figure stated that the water brought by Moses and Isa was refreshing, and as such King Negus had no reason to force Muslims from his lands because of their religion. ${ }^{4}$

Such historical facts indicate that not all non-Muslims have the same attitudes and character, i.e. opposing and fighting Islam and Muslims. Among them, there are those who behave with honor and justice. As humans, non-Muslims may change their attitude towards Islam and the treatment of Muslims. During the time of the Prophet and in the present day, there have been people who commit evil acts towards Muslims and oppose Islam. However, at the same time, there have also been people who act with honor and tolerance. The evil need not be elected as leaders. It is sufficient to consider the kind and tolerant as political leaders.

The Prophet's command that his companions, who had suffered in Mecca, seek political refuge from Negus, the Christian King of Ethiopia who treated Muslims with kindness, may serve as a theological justification for allowing Muslims to elect non-Muslims - those who bear no ill-will towards Islam and its followers - as leaders in Muslim-majority areas.

${ }^{42}$ Ali Ahmad al-Nadwi, Al-Qawaid al-Fiqhiyatu Vol III, (s,1: Darul Kalam, 1994), p. 187

${ }^{43}$ Irfan Syuryahardi Awwas, Citra Orang Kristen di Mata Orang Islam, (Jakarta: Wahdah Press, 2018), p. 62. See also Muhammad Quthub, Salah Paham Terhadap Islam, trans. Hersri (Bandung: Pustaka Salman ITB, n, d,), pp. 306-307.

${ }^{44}$ Irfan Syuryahardi Awwas, Citra Orang Kristen di Mata Orang Islam, p. 63 
The verses that forbid non-Muslims from selecting non-Muslim leaders for Muslimmajority areas can be understood to have been abrogated by verses permitting this, namely verses 7, 8, and 9 of the Sura Al-Mumtahina. Linking the verses that prohibit Muslims from selecting non-Muslim leaders in Muslim-majority areas to the abovementioned verses offers the understanding that this prohibition, as stated by Muhammad Abduh, is subject to the consideration of whether or not said nonMuslims have enmity for Islam and force Muslims from their homelands because of their faith. It is wholly forbidden (haram, حَرَام) to select non-Muslims who have enmity and hatred for Islam, and who treat Muslims arbitrarily, as the leader of Muslims. ${ }^{45}$

From Verse 7 of the Sura Al-Mumtahina, it can be understood that the establishment of harmonious and caring relations between Muslims and the nonMuslims opposed to the Prophet, who drove him from his homeland, was greatly desired. Likewise, Verse 8 and 9 of this sura explain that God does not prohibit Muslims from behaving kindly and justly to non-Muslims who are not their enemies. The prohibition against selecting non-Muslims as leaders is limited to non-Muslims who oppose Islam and fight against Muslims solely for their religious teachings (i.e. for being Muslim), drive Muslims from their homelands, or assist others in doing so. The prohibition against electing non-Muslims as leaders of Muslim-majority areas applies to non-Muslims who oppose Islam and battle against Muslims, as well as those non-Muslims who support them in their opposition. Aside from these two groups, non-Muslims may receive kind and just treatment from Muslims. ${ }^{46}$ This is the ideal tolerance taught by Islam and applied in governance and socio-political affairs. One form of kind and just treatment is giving and recognizing non-Muslims equal political rights to Muslims, including free access to practical politics and the ability to be selected as government or political leaders.

As such, verses 7, 8, and 9 of the Sura Al-Mumtahina are valid naskh (سنخ), clarifying that the prohibition against electing non-Muslims as political and government leaders in Muslim-majority areas is based on their opposition to Islam and enmity for Muslims, rather than their different religion or faith.

Viewing the verses that prohibit non-Muslims from serving as leaders of Muslim-majority areas in conjunction with the verses that allow such leadership for non-Muslims who have no enmity for Islam or its followers and who honor and respect Muslims, it may be concluded that the prohibition only applies to nonMuslims who oppose Islam and do battle against Muslims.

From the above perspective, the influence of classical Islamic jurisprudence on this prohibition is apparent. In other words, the lack of recognition and acceptance for non-Muslims political right to be elected as government leaders in Muslim-majority

${ }^{45}$ Muhammad Abduh and Rasyid Ridha, Tafsir al-Qur'an al-Hakim (Tafsir al-Manar) Vol. 6, (Beirut: Dar al-Ma'arifah, n. d.), p. 429.

${ }^{46}$ Ahmad Hidayat Buang, Nik Yusri Musa, and Nazri Muslim. "Hubungan Etnik di Malaysia dari Perspektif Islam", Kajian Malaysia, vol. 29, no.1, (2011): pp. $1-28$. See also Relations in Malaysia From an Islamic Perspektive, Jounal, https://doaj.org/articel 2015 
areas was formulated when relations between different religious communities were full of conflict, as reflected in the revelation of the Qur'anic verses that prohibit the selection of a non-Muslim as a leader for Muslims. In the early years of Islam, Muslims focused predominantly on expanding their political influence, leading them to conquer non-Muslim areas. This led to the emergence of the dzimmi and political protections for non-Muslims living in Muslim-controlled areas. Presently, however, Muslims live in vastly different socio-political conditions. Relations between religious communities and groups are oriented more towards peace, tolerance, and equality, towards citizenship in pluralist societies. ${ }^{47}$ As such, the most relevant and appropriate approach for this modern pluralist society is that taken by Muslim figures in the Islamic organizations and political parties in Makassar, in which non-Muslims are considered to have political rights equal to Muslims, including the right to govern over Muslim-majority areas.

The public opinion so developed has rejected the classical Islamic jurisprudence that positioned non-Muslims as second-class citizens, beneath Muslims, and limited the political rights of non-Muslim citizens in Muslim-majority areas, as formulated by Sayyid Quthub, Sayyid Hawa, Abu A'la Al-Maududi, and similar scholars.

\section{F. Conclusion}

Based on the above discussion, it is apparent that non-Muslims enjoy the same political rights as Muslims within the government of Makassar, a majority Muslim region. Although in the course of governance in Makassar, non-Muslims have yet to take roles as political leaders, this does not mean they lack the political rights to do so. Rather, this can be attributed mostly to socio-political and cultural conditions that do not support or benefit non-Muslims attempting to compete against the majority Muslim population.

These socio-political and cultural conditions are, first, the "political domain" not drawing the serious attention and interest of non-Muslim politicians. NonMuslims, particularly the ethnic Chinese, tend to be attracted to alternative channels and other fields (particularly trade) because these are considered to offer a more promising future than politics. In other regions in Indonesia, the political arena is sometimes capable of drawing the serious attention and interest of non-Muslims, who compete against other religious groups (i.e. Muslims) as mainstream candidates. This can be seen, for example, in Bangka Belitung, where the regent is a non-Muslim of Chinese heritage, and in West Kalimantan, where the deputy governor is also a nonMuslim of Chinese heritage. Likewise, in the Jakarta Capital Region, which is just now entering its second round of gubernatorial elections, the incumbent governor Basuki Cahya Purnama is of Chinese descent. This may occur within majority Muslim areas because the general and regional elections, as democratic vessels for leadership selection, are very subjective.

\footnotetext{
${ }^{47}$ Muhammad Yasir, "Makna Toleransi dalam Al-Qur'an", Jurnal Ilmu Ushuluddin, vol. 22 (2), 2018, pp. 22
} 
Second, the religious ties between Muslims in Makassar are very strong and rooted in the region's culture. As such, non-Muslims have difficulty establishing political communications with members of the community, who tend to have fundamentalist and even radical religious understandings.

Third, it is possible that non-Muslim politicians in the region, both individually and as a group, lack the managerial quality and prestige enjoyed by Muslim politicians, and thus face severe obstacles in competing. This condition is exacerbated by their lack of effort to establish intense, friendly, and polite political communications with other political parties and religious majority. This is particularly problematic given that Muslim politicians have opened and maintained increasingly intensive political communications, thus drawing the populace's sympathy.

The socio-political and cultural conditions outlined above may be technical reasons why non-Muslim elites have yet to play significant political roles or successfully compete against Muslim politicians for strategic positions such as regional leaders.

\section{BIBLIOGRAPHY}

\section{Al-Qur'an dan Terjemahnya}

Abduh, Muhammad and Rasyid Ridha, Tafsir al-Qur'an al-HakimTafsir al-Manar Vol. 6, Beirut: Dar al-Ma'arifah, n.d.

An-Na'im, Abdullah Ahmed, Islam dan Negara Sekuler: Menegosiasikan Masa Depan Syari'ah, Bandung: Mizan Pustaka, 2017.

Awwas, Irfan Syuryahardi, Citra Orang Kristen di Mata Orang Islam, Jakarta: Wahdah Press, 2014.

Aswandi, Babi dan Chalis Raisah, "Negara Hukum dan Demokrasi Pancasila dalam kaitannya dengan Hak-hak Asasi Manusia (HAM)", Jurnal Pembangunan Hukum Indonesia, vol. 1, no. 1, (tahum 2019),

Buang, Ahmad Hidayat, Nik Yusri Musa, and Nazri Muslim. "Hubungan Etnik di Malaysia dari Perspektif Islam", Kajian Malaysia. Vol. 29 no. 1, (2017).

Budiardjo, Meriam, Dasar-dasar Ilmu Politik, Jakarta: Gramedia Pustaka Utama, 2012. 
Department of Religion, Directorate-General for the Guidance of Islamic Organizations, Project for Improving Religious Higher Education Infrastructure and Facilities. Ensiklopedia Islam, Jakarta: Anda Utama, n.d.

Edwin M.B. Tambunan, "Demokrasi, Sistem Pemilu, Dan Pengelolaan Kinflik Etnik", Jurnal dan Ilmu Sosial dan Ilmu Politik, vol. 5, no. 19, (Juni 2019),

Elster, Jon, Marxisme: Analisis Kritis, Jakarta: Prestasi Pustaka, 2012.

Gerung, Rocky, "Agama dan Negara" Paper presented at the monthly discussion forum "Mendefinisikan Indonesia; Politik Identitas dalam Koridor Demokrasi: Perspektif Komunitas Agama", held by the Tirta Foundation in collaboration with the Research Institute, UIN Alauddin Makassar, 26 December 2017

Hawwa, Sayyid, al-Madkhal Ila Da'wa Ikhwan al-Muslimin, s.n.., n.d.

Hussain, Syekh Syaukat, Hak-hak Asasi Manusia dalam Islam, Jakarta: Gema Insani Press, 2018

I. Doi, Abdur Rahman, Shari'ah: The Islamic Law, Kuala Lumpur: A.S. Noordeen, 2012.

Iqbal, Mahathir Muhammad. "Dinamika Wacana Formalisasi Syariat dalam Politik: Ikhtiar Menemukan Relevansi Relasi Agama dan Negara Perspektif Indonesia", Walisongo: Jurnal Penelitian Sosial Keagamaan", vol. 22 no.1, (2014).

Jafar, Usman, Egalitarianisme dalam Islam: Refleksi Pemikiran Atas Hak-hak Politik Minoritas Non-Muslim di Tengah-tengah Mayoritas Muslim, Makassar: Alauddin University Press, 2016

Khallaf, Abdul al-Wahab, al-Siyasah al- Syar'iyah aw Nizham al-Dawlah alIslamiyyah fi al-Sur'un al-Dusturiyyah wa al-Kharajiyyah wa al-Malikiyah, Cairo: Dar al-Anshar, 1977.

Kompilasi Hukum Tata Negara, Edisi Paling Lengkap, Yogyakarta: RIAK, 2017.

Kuper, Adam, and Jessica Kuper, Ensiklopedi Ilmu-ilmu Sosial. Jakarta: RajaGrafindo Persada, 2009.

Mhammad Ash-Shalabi, Ali, Ad-Daulah Al-Haditsah Al-Muslimah: Do'a 'imuha wa Wazha'ifuha, terj. Ali Nurdin, Negara Islam Modern; Menuju Baldatun Thayyibatun wa Rabbun Ghafur, Jakarta Timur: Pustaka Al-Kausar, 2017

Madjid, Nurcholish, Islam Kemoderenan dan Keindonesiaan, Bandung: Mizan, 1987.

Mahendra, Yusril Ihza, Modernisme dan Fundamentalisme dalam Politik Islam, Jakarta: Pramadina, 1999.

Marlow, Louis, Masyarakat Egalitarian, Bandung: Mizan, 1999.

Muhammad, Rusjdi Ali, Hak-hak Asasi Manusia dalam Perspektif Syari'at Islam, Jakarta: Ar-Raniry Press, 2014.

Musda, Mulia, and Anik Farida, Perempuan dan Politik, Jakarta: Gramedia Pustaka Utama, 2015. 
Qasim Ja'far, Muhammad Anis, Perempuan dan Kekuasaan: Menelusuri Hak Politik dan Persoalan Gender Dalam Islam, Bandung: Zaman Wacana Mulia, 1998.

Quthub, Muhammad, Salah Paham Terhadap Islam, trans. Hersri, Bandung: Pustaka Salman ITB, 1992.

Quthub, Sayyid Fi Zilal Al-Qur'an, Vol. 2, Beirut: Dar al-Syuruq, n.d.

Rais, M. Dhiauddin, Teori Politik Islam, Jakarta: Gema Insani, 2001.

Rosyd, Moh. "Harmoni Kehidupan Sosial Beda Agama dan Aliran di Kudus", Journal Addin, vol. 17 no. 1, (2015).

Rosyada, Dede, et al. Pendidikan Kewargaan (Civic Education): Demokrasi, Hak Asasi Manusia dan Masyarakat Madani, Jakarta: ICCE UIN Syarif Hidayatullah Jakarta, 2018.

Sirajuddin dan Winardi, Dasar-dasar Hukum Tata Negara Indonesia, Malang: Setara Press, 2015

Silvita, Mary, "Presiden Non-Muslim dalam Komunitas Masyarakat Muslim", Islamica: Journal Studi Keislaman, vol. 7 no. 1,( 2014).

Syarif, Mujar Ibnu, Presiden Non-Muslim di Negara Muslim, Jakarta: Pustaka Sinar Harapan, 2019.

Tahhan, Musthafa Muhammad, Tantangan Politik Negara Islam, Malang: Pustaka Zamzami, 2013.

Tahqiq, Nanang (ed.), Politik Islam, Jakarta: Kencana, 2014.

Thaha, Anis Malik, Tren Pluralisme Agama: Tinjauan Kritis, Jakarta: Gema Insani, 2017.

Thohari, A. Ahsin. Hak-Konstitusional dalam Hukum Tata Negara Indonesia, Jakarta: Erlangga, 2016

UUD 45 yang Sudah Diamandemen dengan Penjelasannya, Surabaya: Karya Ilmu, 2014-2015.

Usman, "Pilkada Dan Konflik Horizontal: Telaah Atas Pemilukada di Kota Makassar", Al-Daulah Jurnal, Hukum Pidana \& Ketatanegaraan, vol. 7, no.2 ( Desember, 2018)

maan Dalam Islam" (Telaah Atas Pemikiran Politik Islam), Al-Daulah Jurnal Hukum Pidana \& Ketatanegaraan, vol. 6, no.1 (2017)

Van Dijk, Pieter, and Peter Baehr, Instrumen Internasional Pokok Hak-hak Asasi Manusia, second edition, Jakarta: Yayasan Obor Indonesia, 2001.

Wahid, Abdurrahman, "Presiden dan Agama", in Politik Demi Tuhan: Nasionalisme Religius di Indonesia, Bandung: Pustaka Hidayat, 1999.

Yasir, Muhammad. "Makna Toleransi dalam Al-Qur'an", Jurnal Ilmu Ushuluddin, vol. 22 no.2, (2014). 


\section{Guidelines}

\section{Submission of Article}

urnal Adabiyah welcomes the articles submission with the main themes on Humanities and Islamic Studies with the emphasis on interdisciplinary and intertextuality approach. Adabiyah is thematicly published twice in a year. ie the theme of the humanities in June and the Islamic Study in December.

Themes related to Islamic Studies are textual studies, scriptural traditions, Islamic law, and theology; and those related to Humanities are language, literature, history, and culture. This scholarly journal Guarantees that the editor decision based on the peer review results will not exceed 30 days from the paper submission date.

Authors are invited to read our archives; to find the relevant topics for the journal, and to submit complete unpublished scientific researches, which are not under review in any other conferences or academic journal.

\section{PUBLICATION ETHIC}

Publication Ethic and Malpractice Statement

Jurnal Adabiyah is a peer-reviewed journal, published twice a year by the Faculty of Adab and Humaniora, Alauddin State Islamic University of Makassar Indonesia. It is available online as open access sources as well as in print. This statement clarifies ethical behaviour of all parties involved in the act of publishing an article in this journal, including the author, the editor-in-chief, the Editorial Board, the reviewers, and the publisher. This statement is based on COPE's Best Practice Guidelines for Journal Editors.

Ethical Guideline for Journal Publication

The publication of an article in Jurnal Adabiyah, is an essential building block in the development of a coherent and respected network of knowledge. It is a direct reflection of the quality of the work of the authors and the institutions that support them. Peer-reviewed articles support and embody the scientific methods. It is therefore important to agree upon standards of expected ethical behavior for all parties involved in the act of publishing: the author, the editor, the reviewer, the publisher, and the society. As the publisher of Jurnal Adabiyah, the Faculty of Adab and Humaniora takes its duties of guardianship over all stages of publishing seriously and it recognizes its ethical and other responsibilities. The Faculty of Adab and Humaniora committed to ensuring that advertising, reprint or other commercial revenue has no impact or influence on editorial decisions.

\section{Publication Decisions}

The editors of Jurnal Adabiyah is responsible for deciding which articles submitted to the journal should be published. The validation of the work in question and its importance to researchers and readers must always drive such decisions. The editors may be guided by the policies of the journal's editorial board and constrained by such legal requirements as shall then be in force regarding libel, copyright infringement, and plagiarism. The editors may confer with other editors or reviewers in making their decisions.

\section{Plagiarism Screening}

It is basically author's duty to only submit a manuscript that is free from plagiarism and academically malpractices. The editor, however, will check all submitted papers through Turnitin.

\section{Fair Play}

An editor at any time evaluates manuscripts for their intellectual content without regard to race, gender, sexual orientation, religious belief, ethnic origin, citizenship, or political philosophy of the authors. 


\section{Confidentiality}

The editors and any editorial staff must not disclose any information about a submitted manuscript to anyone other than the corresponding author, reviewers, potential reviewers, other editorial advisers, and the publisher, as appropriate.

\section{Disclosure and Conflicts of Interest}

Unpublished materials disclosed in a submitted manuscript must not be used in editors' own research without the express written consent of the author.

\section{DUTIES OF AUTHORS}

\section{Reporting Standards}

Authors of reports of original research should present an accurate account of the work performed as well as an objective discussion of its significance. Underlying data should be represented accurately in the paper. A paper should contain sufficient detail and references to permit others to replicate the work. Fraudulent or knowingly inaccurate statements constitute unethical behaviour and are unacceptable.

\section{Originality and Plagiarism}

The authors should ensure that they have written entirely original works, and if the authors have used the work and/or words of others that this has been appropriately cited or quoted.

\section{Multiple, Redundant, or Concurrent Publication}

An author should not in general publish manuscripts describing essentially the same research in more than one journal or primary publication. Submitting the same manuscript to more than one journal concurrently constitutes unethical publishing behaviour and is unacceptable.

\section{Acknowledgement of Sources}

Proper acknowledgment of the work of others must always be given. Authors should cite publications that have been influential in determining the nature of the reported work.

\section{Authorship of the Paper}

Authorship should be limited to those who have made a significant contribution to the conception, design, execution, or interpretation of the reported research. All those who have made significant contributions should be listed as co-authors. Where there are others who have participated in certain substantive aspects of the research project, they should be acknowledged or listed as contributors. The corresponding author should ensure that all appropriate co-authors and no inappropriate co-authors are included on the paper, and that all co-authors have seen and approved the final version of the paper and have agreed to its submission for publication.

\section{Disclosure and Conflicts of Interest}

All authors should disclose in their manuscript any financial or other substantive conflict of interest that might be construed to influence the results or interpretation of their manuscript. All sources of financial support for the project should be disclosed.

\section{Fundamental errors in Published Works}

When an author discovers a significant error or inaccuracy in his/her own published work, it is the author's obligation to promptly notify the journal editor or publisher and cooperate with the editor to retract or correct the paper.

\section{PLAGIARISMI}

It is basically author's duty to only submit a manuscript that is free from plagiarism and academically malpractices. The editor, however, will check all submitted papers through Turnitin. 


\section{AUTHOR GUIDELINES}

\section{Guidelines for online submission:}

1. Author should first register as Author to the website of Jurnal Adabiyah. Click the menu "register" to register as an author.

2. Once after the author is registered, please login to the website of Jurnal Adabiyah and submit the article through online submission (with the stat us of active submissions).

3. The article should follow the standard template of Jurnal Adabiyah provided in the website.

4. The citation and bibliography should follow the Turabian citation style.

5. Author is restricted not to send his/her article to another journal before having confirmation from the editorial team (approximately 4 weeks right after the article submitted).

6. Author should follow editorial decisions and recommendations related to the article completion. All reviews and assessements will be informed through online submission.

Article submitted to Jurnal Adabiyah editorial board must follow these guidelines:

1. Article should be based on the scientific research in the field humanities and Islamic studies;

2. Article must be an original work and has not been previously published;

3. Article should be written in Arabic or English languages;

4. Article must be typed in one-half spaced on A4-paper size;

5. Article's length is about $6,000-10,000$ words;

6. All submission must include a 150-250 word abstract;

7. Abstract should be written in 3 languages; Arabic, English, and Bahasa;

8. Full name(s) of the author(s) must be stated, along with his/her/their institution and complete address;

9. All submission should be in OpenOffice, Microsoft Word, RTF, or WordPerfect document file format;

10. Bibliographical reference must be noted in footnote and bibliography according to Jurnal Adabiyah style. In addition, it is suggested for author(s) to use reference manager tools such as 30 MENDELEY or 2 otero

When a source is cited for the first time, full information is provided: full name(s) of author(s), title of the source in italic, place of publication, publishing company, date of publication, and the precise page that is cited. For the following citations of the same source, list the author's last name, two or three words of the title, and the specific page number(s). The word ibid., op.cit., and loc.cit. are may not be used any more.

\section{Example in footnotes:}

${ }^{1}$ Mircea Eliade (ed.), The Encyclopedia of Religion, vol. 8 (New York: Simon and Schuster, 1995), h. 18.

${ }^{2}$ Norman Daniel, Islam and the West (Oxford: One World Publications, 1991), h. 190.

${ }^{3}$ Syeikh Ja'far Subhānī, Mafăhim Al-Qur'ān (Beirut: Mu'assasah Al-Tarikh Al-'Arabī, 2010)., Juz 5, h. 231. 
${ }^{4}$ Syeikh Ja'far Subhānī, Mafăhim Al-Qur'ān, h. 8-9.

\section{Example in bibliography:}

Subhānī, Syeikh Ja'far. Mafāhim Al-Qur'ān. Beirut: Mu'assasah Al-Tarikh Al-'Arabī, 2010.

Eliade, Mircea (ed.). The Encyclopedia of Religion, vol. 8. New York: Simon and Schuster, 1995.

Daniel, Norman. Islam and the West. Oxford: One World Publications, 1991.

Shihab, Muhammad Quraish. Sunnah-Syiah Bergandengan Tangan: Mungkinkah? Kajian Atas Konsep Ajaran Dan Pemikiran. Cet. III. Jakarta: Lentera Hati, 2007.

Detail informations of the footnotes:

1. Holy book

Al-Qur'ân, Al-Baqarah/2: 185.

Perjanjian Baru, Mrk. 2: 18.

2. Qur'anic translation

${ }^{1}$ Departemen Agama RI, al-Qur'an dan Terjemahannya (Jakarta: Darus Sunnah, 2005), h. 55.

3. Book

${ }^{1}$ Muḥammad 'Ajjaj al-Khațib, Ușl al-Hadith: 'Ulumuh wa Mușțalaḥuh (Beirut: Dâr al-Fikr, 1989), h. 57.

4. Translation Books

${ }^{1}$ Toshihiko Izutsu, Relasi Tuhan dan Manusia: Pendekatan Semantik terhadap al-Qur'an, terj. Agus Fahri Husein dkk (Yogyakarta: Tiara Wacana, 2003), h. 14.

5. Voluminous book

${ }^{1}$ Muḥammad al-Ṭâhir b. 'Ashur, al-Tạnn̄̄r wa al-Tanwīr, Vol. 25 (Tunisia: Dâr al-Suhûn, 2009), h. 76.

${ }^{1}$ Muḥammad b. Ismā‘īl al-Bukharī, al-Jami` al-Ṣahịḥ, Vol. 2 (Beirut: Dar al-Kutub al-‘Ilmìyah, 1999), h. 77.

6. Article in book

${ }^{1}$ Sahiron Syamsuddin, "Metode Intratekstualitas Muhammad Shahrur dalam Penafsiran al-Qur'an" dalam Abdul Mustaqim dan Sahiron Syamsuddin (eds.), Studi al-Qur'an Kontemporer: Wacana Baru Berbagai Metodologi Tafsir (Yogyakarta: Tiara Wacana, 2002), h. 139.

7. Article in encyclopaedia

${ }^{1}$ M. Th. Houtsma, "Kufr” dalam A. J. Wensinck, at al. (ed.), First Encyclopaedia of Islam, Vol. 6 (Leiden: E.J. Brill, 1987), h. 244.

8. Article in journal

${ }^{1}$ Muhammad Adlin Sila, "The Festivity of Maulid Nabi in Cikoang, South Sulawesi: Between Remembering and Exaggerating the Spirit of Prophet", Studia Islamika 8, no. 3 (2001): h. 9.

9. Article in mass media

${ }^{1}$ Masdar F. Mas'udi, "Hubungan Agama dan Negara", Kompas, 7 Agustus 2002. 
10. Article in Internet

${ }^{1}$ Muhammad Shahrūr, "Reading the Religious Teks: a New Approach" dalam http://www.shahrour.org/25 Februari 2010/diakses 5 Juni 2010.

11. Thesis or dissertation

${ }^{1}$ Syahruddin Usman, "KinerjaGuru Penddikan Agama Islam pada SMAN dan SMKN Kota Makassar”, Disertasi (Makassar: PPs UIN Alauddin, 2010), h. 200.

\section{COPYRIGHT NOTICE}

Authors who publish with this journal agree to the following terms:

1) Authors retain copyright and grant the journal right of first publication with the work simultaneously licensed under a Creative Commons Attribution License that allows others to share the work with an acknowledgement of the work's authorship and initial publication in this journal.

2) Authors are able to enter into separate, additional contractual arrangements for the non-exclusive distribution of the journal's published version of the work (e.g., post it to an institutional repository or publish it in a book), with an acknowledgement of its initial publication in this journal.

3)Authors are permitted and encouraged to post their work online (e.g., in institutional repositories or on their website) prior to and during the submission process, as it can lead to productive exchanges, as well as earlier and greater citation of published work (See The Effect of Open Access). 